\title{
Librarianship in Iran
}

Iranian library development is of recent origin, and the establishment of a national library association is now being attempted. Trained people are badly needed to effect modern library administrative practices. Library materials are also needed to support curricular programs and to stimulate research, and the status of librarians needs improvement. Career opportunities in Iran are unlimited.

$P$ countries, Iran has a limited history of library development and no concept of modern librarianship. In recent months, in the attempt to organize an Iranian Library Association, it was found that there were no more than a half dozen Iranian-born librarians with professional degrees; all of these held positions in the capital, Tehran. The improvement and development of libraries throughout the country has only recently begun, largely through the advice and assistance of foreign librarians on short-term assignments. Since such assistance is temporary and limited, it is obvious that Iran's crucial need is a "crash" program for the training of those who can become the nucleus of a new profession of librarianship. At the present time, because of long-standing traditions and the attached prestige, most of the academically promising young people go into medicine, engineering, or careers growing out of a major in economics. Such professions have status, provide security, and offer the best promise of employment. While there have been provincial colleges in Iran for some years, university education as we know it is a relatively recent development. $^{1}$

\footnotetext{
${ }^{1}$ Not until 1934 were the separate "colleges" of the present University of Tehran consolidated; Pahlavi University, Shiraz, succeeded the provincial University of Shiraz, founded in 1952.

Mr. Deale is Director of Libraries, Beloit College, Beloit, Wisconsin.
}

The desperate need for trained personnel can best be illustrated by the example of Pahlavi University in Shiraz which has no permanent director of libraries, no centralized book collection, no centralized library budget, and no professional Iranian staff. Five libraries, operating more or less independently, have little control over either book funds or the purchase of periodical subscriptions. The deans of the various faculties (agriculture, arts and sciences, engineerings, and medicine), allocate book and periodical funds by departments. The situation is not much brighter at the University of Tehran, where, in spite of a central library, there are some thirtyodd departmental collections with little over-all supervision or control. University administrators, with many problems demanding their attention and time, cannot be wholly blamed. With little concept of the meaning of library service to students and faculty, and with no one to point out the basic and significant role of libraries and librarians in the academic community, it is understandable that the profession has been ignored or neglected for so long.

In tentative reports presented at a midwinter Fulbright conference concerned with the problems of Iranian higher education, ${ }^{2}$ Margaret L. Hopkins, Fulbright consultant to the University

${ }^{2}$ Fulbright Conference, Tehran, January 19-20, 1966; sponsored by the United States Commission for Cultural Exchange with Iran. 
of Tehran, and the author emphasized the crucial need for the training of professional Iranian librarians. The alternatives (which should be pursued simultaneously during the next few years) are: (1) study abroad for the best qualified university graduates interested in a career in librarianship; and (2) establishment of a four-year and a five-year program in library education. Both consultants have outlined and recommended proposals for the establishment of such programs. While it is not likely that the Ministry of Education (Tehran) will approve two programs, there is no reason why Iran could not support both. There are medical and dental faculties in Tehran, Shiraz, and Meshed; why not more than one school of library service?

In the proposals recommended to the administration of Pahlavi University, the report of Lester Asheim, director, ALA International Relations Office, was followed. Dr. Asheim spent a week in Shiraz during October 1965, talking with librarians, administrators, and others. In his carefully written memorandum to the Chancellor and Vice-Chancellor, ${ }^{3}$ he urged a program of library education in three stages. The first stage, currently in operation, is the conducting of library science classes for present library personnel. The second stage, which has the approval of the Pahlavi University administration, will be to institute a department of library science within the college of arts and sciences next year (1966-67), and offer a major subject concentration. "The third step-and we are agreed that this is the ultimate objective towards which present plans and commitments should be directed-will be the establishment of a professional school of library service, which will offer its own degree, and provide course work at the fifth-year level for full professional qualification beyond the under-

\footnotetext{
Memorandum to Chancellor A. Alam and Dr. Z. Ghorban, Vice-Chancellor, Pahlavi University, Shiraz, Iran (October 20, 1965), mimeographed.
}

graduate major."4 Since the development of a library science program of such scope is not accomplished overnight, and gradual evolvement assures the best chances for success, there is no time to delay in implementing the recommendations. Both programs are needed nowthe four-year BA program will prepare students for beginning-level professional positions and will act as an avenue leading to the fifth year which will be designed to prepare top-level administrators, specialists, and instructors for the library science program itself.

In keeping with the present organization of the College of Arts \& Sciences, it is recommended that librarianship be defined as a Social Science for purposes of identifying "peripheral" and "cross-cultural" course content. The identification with the Social Sciences places the emphasis upon the role of libraries and the service to readers which is their goal. It recognizes not only the library which serves the academic community, but also the library which serves the general public, the child and adolescent, the subject specialist and the technician. It places the library beside the school, college, and university as an agency of education and enlightenment; it places the librarian along side the educator, journalist, broadcaster, film-maker and writer as a conveyor of information and an active agent in the process of communication at all levels. This is the social role of the library which is already recognized, not only in the United States, but also notably in Russia, the Scandinavian countries, Britain, France and many of the more rapidly developing new nations in Africa and Asia. ${ }^{5}$

Pahlavi University, patterned after American-type universities, is a rapidly growing and expanding institution. Next Fall, it plans to double the enrollment of its entering class. This past year it has built new classroom buildings for the biological and physical sciences; a temporary undergraduate library is being completed. It receives adequate financial support from the government, and from

- Asheim Report, p. 3.

Ibid. 
outside sources. Its student body is bilingual, with courses being taught in English. Simultaneous with the development of a program of library education, the university must give serious attention to the condition of its various libraries. While well-trained personnel are needed to increase the effectiveness of library service and physical needs cannot be overlooked, good libraries consist of books and related materials that implement the curriculum and stimulate research. Good libraries do not just grow; they must be carefully built and given thoughtful direction by trained experts (both librarians and teaching faculty) if the cumulative results are to be significant. Students and faculty deserve a strongly supported library program if they are not to be deprived of one of the basic, essential ingredients of an academic community.

The challenge and opportunity for librarianship in Iran is unlimited. There are no hide-bound traditions to overcome, except within the field of education itself; there is evidence of interest by the Iranian government in all forms of educational advancement (including libraries); and there is a variety of opportunities waiting for the graduate looking for a new adventure and a satisfying career. With the acceleration of Mohammad Reza Shah's program for the elimination of illiteracy, there will be increasing need for books, libraries, and librarians at all levels. If, at both the secondary and university level, Iranian students are given the chance to learn about career opportunities in librarianship and if they can be assured that it will have status and remuneration comparable to other developing professions in their progressive country, there is little reason to believe that many young men and women would not choose to contribute to the progress of their country by preparing themselves for a future in librarianship! Of course, these are rather big "ifs" that will require the dedicated efforts of Iranian educators and administrators, with the guidance and assistance of foreign consultants.

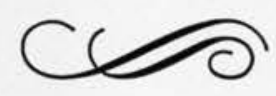

